\title{
Periodické vysychání toků: další faktor negativně ovlivňující populace našich raků
}

\section{JITKA SVOBODOVÁ, DAVID FISCHER, EVA SVOBODOVÁ, PAVEL VLACH}

\author{
Klíčová slova: Austropotamobius torrentium - Astacus astacus - sucho - negativní faktory - invazní druhy - račí mor
}

\section{SOUHRN}

Periodická sucha v malých vodních tocích jsou způsobena klimatickými změnami, ale i nevhodným hospodařením se srážkovou i povrchovou vodou. Působí-li tyto faktory najednou, dochází k rychlým poklesưm vodní hladiny až úplnému vyschnutí dlouhých úseků toků. Takové změny jsou pro vodní faunu, potažmo zvláště chráněné druhy raků, často fatální.

Tento príspěvek přináší řadu príběhů roku 2015 spojených se suchem, raky a jejich záchrannými transfery. Tyto záchranné transfery byly $v$ mnoha prípadech provedeny neodborně, bez patřičných povolení a mohly více uškodit než pomoci. Proto se tento príspěvek zabývá též legislativními a odbornými aspekty takovýchto záchranných transferů a navrhuje postupy, jak v těchto prípadech správně postupovat.

\section{ÚVOD}

Na přelomu tisíciletí byla na mnoha tocích opakovaně zaznamenána historická minima v průtocích za období, během nichž jsou toky sledovány [1]. V roce 2003 a 2015 hladiny řek viditelně poklesly zejména po průběhu extrémně teplého počasí. Velmi nízké průtoky až vyschnutí toku mají závažné dopady na přežívání vodních organismů, ale negativně ovlivňují i jakost vody [2]. Kromě ryb ohrožují vyschlé toky i vodní makrozoobentos, mezi který patři i kriticky ohrožené druhy raků.

$\checkmark$ České republice se vyskytuje pět druhů raků, jen dva jsou zde ale původní - rak kamenáč (Austropotamobius torrentium Schrank, 1803) a rak ríční (Astacus astacus L.). Oba druhy patř́ mezi zvláště chráněné druhy v kategorii kriticky ohrožený [3, 4]. Kromě těchto dvou druhů se v ČR vyskytuje rak bahenní (Astacus leptodactylus Eschscholtz, 1823), původem z východní Evropy. Byl u nás vysazován na konci 19. století jako náhrada za račím morem zdecimované populace raků říčních. I přesto je chráněn zákonem, a to jako ohrožený druh [3, 4].

Další dva nepůvodní druhy, rak pruhovaný (Orconectes limosus Rafinesque, 1817) a rak signální (Pacifastacus leniusculus Dana, 1852) pochází ze Severní Ameriky a jsou spojeny s račím morem - onemocněním, způsobeným parazitickou rasovkou (oomycetou) hnilečkem račím (Aphanomyces astaci Schikora, 1906). Americké druhy raků, samy vưči infekci výrazně odolné, jsou přenašeči tohoto onemocnění, a v důsledku jejich opakovaných nechtěných (v polovině 19. století) nebo záměrných (v druhé polovině 20. století) introdukcí do Evropy decimuje tato nemoc populace původních raků již po desítky let.

Kromě vysychání toků existuje v současné době celá řada vlivů, které mají negativní dopad na populace původních raků. Jedná se především o změny v hydromorfologii toků [5], predaci [6] nebo lokální otravy [7, 8]. Nejvýraznější hrozbou však stále zůstávají americké druhy raků a jejich šíření; at’ již přirozenou cestou po Labi z Německa, tak i nezodpovědnými přenosy raků na nové lokality, především sportovními i profesionálními rybáři nebo akvaristy [9].

Na vysychání lokalit se podílí řada faktorů. Prvotní význam mají postupné změny klimatu, doprovázené predevším nerovnoměrnou distribucí srážek. Dalším takovým faktorem je hospodaření se srážkovou vodou: úkolem je především zabránit rychlému odtoku srážkových vod, a naopak podporovat zadržení vody v krajině. Bohužel v řadě prípadů se děje pravý opak - celé plochy jsou betonovány nebo asfaltovány, takže deštová voda rychle odtéká kanalizačními svody do vodních toků. Ty byly $v$ minulosti v rámci proti- nebo popovodňových úprav v celých úsecích naprímeny a kanalizovány a jejich hloubková diverzita je pak minimální. Následné sucho způsobí, že celé stovky metrů koryt vodních toků jsou zcela bez vody - v naprímeném korytu voda odteče, místo aby v době sucha zůstala v hlubokých tůňkách, sloužících jako dočasné refugium pro množství vodní fauny. Posledním, i když nezanedbatelným faktorem pưsobícím často paralelně s oběma výše uvedenými, je ještě nevhodné hospodaření s vodou, která ve vodních tocích zůstává. Sem patří především hospodaření na rybnících v povodí - jedná se $v$ zásadě o nedodržování manipulačního řádu; $v$ době sucha se snaží rybářský hospodář zachránit spiše "vlastní ryby" v rybníce než navazující vodní toky. Nezanedbatelné je také využívání vody $v$ obydlích $v$ blízkosti vodních tokư, především na zalévání zahrad, trávníků nebo čerpání vody do bazénů.

Při dlouhotrvajícím suchu hladiny vodních toků stále klesají, v menších tocích stoupá teplota vody a její jakost se zhoršuje. Se zvyšující se teplotou a vyšším znečištěním klesá ve vodě obsah kyslíku, tak potřebného pro život vodních organismů. V řadě prípadů jsou jako první postiženy ryby, především druhy náročné na obsah kyslíku, jako jsou ryby lososovité, pstruh nebo lipan, dále vranka obecná nebo střevle potoční. Při snižující se hladině se ryby stahují do tůní a je jen otázkou, zda daná tůň při pokračujícím vysychání skutečně poslouží jako dobré refugium. Do tůní se stahují i raci; ti jsou ovšem oproti rybám ve výhodě. Ve vhodných podmínkách (ve vlhku, napr. pod převislými břehy, v norách, pod kameny) dokáží přežít i v toku, který je zcela bez vody, ostatně i jako další druhy makrozoobentosu. Je ovšem třeba zdůraznit, a zde se vracíme k tématu úprav dna a břehů vodních tokủ, že tok musí takové podmínky poskytovat (zastíněná místa, substrát různé zrnitosti, úkryty $\vee$ podobě kořenové vegetace nebo balvanů).

\section{PŘíBĚHY ROKU 2015}

Prvním zdokumentovaným prípadem vlivu sucha na raky v roce 2015 byla „záchrana“ raků na Janovském potoce. Raci byli na tento potok vysazeni v roce 2007, a to nejspíš bez důkladného průzkumu lokality, protože zde dochází k vysychání toku opakovaně. V roce 2015 zde však došlo k velmi rychlému úbytku vody. 


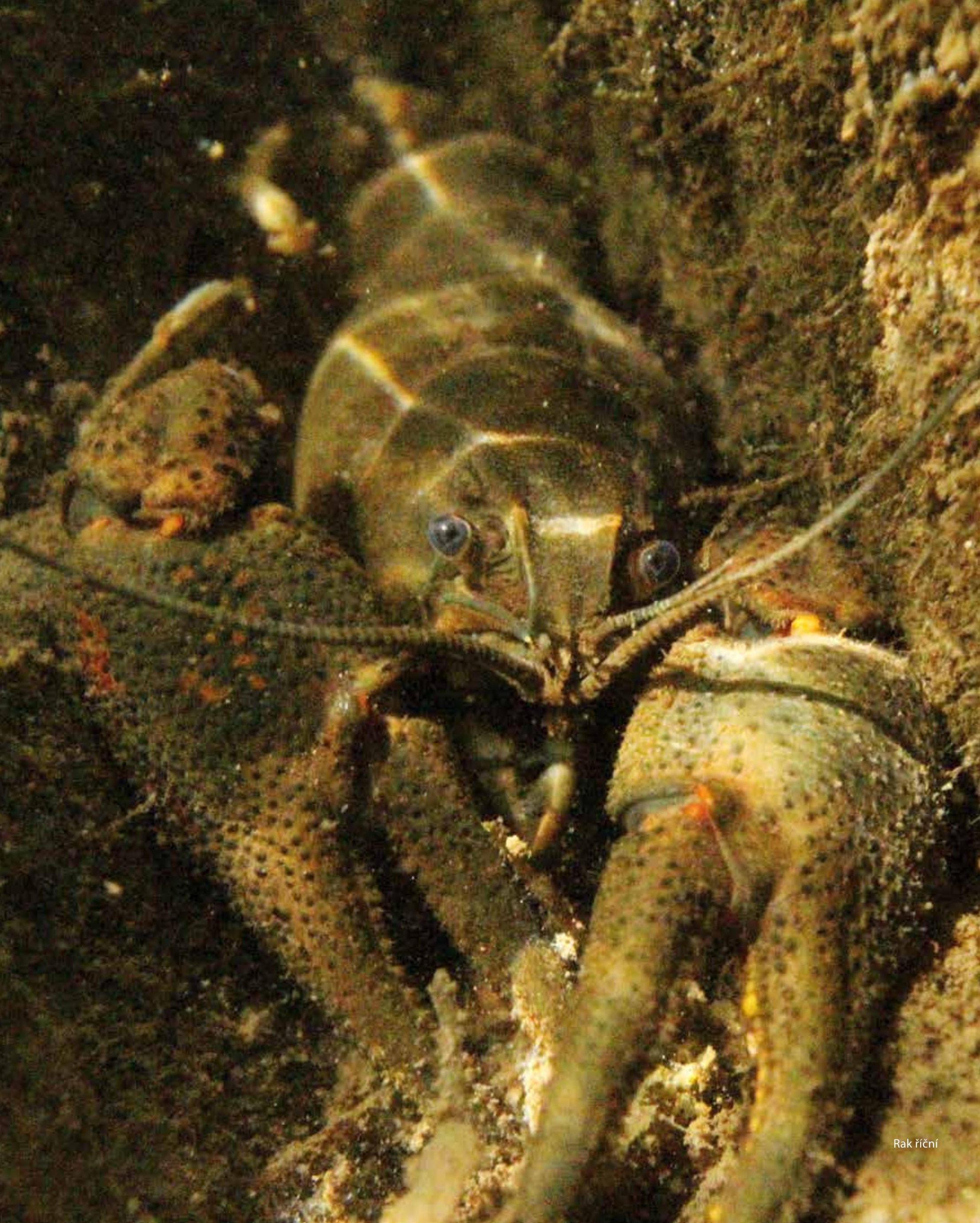


Následkem toho se chopila iniciativy místní skupina ochránců prírody, kteří bez príslušných výjimek a povolení provedli transfer do řady toků v okolí, presestože jim byl autory tohoto článku doporučen jiný postup. V důsledku toho byli vyšetřováni ČıŽP - zcela relevantně, protože tento zásah mohl nadělat více škody než užitku (viz dále).

K záchrannému transferu se uchýlili také na říčce Brzina na Př́bramsku. Zde pracovníci společnosti Ochrany fauny ČR přestěhovali přibližně pět set raků do náhonu Kunclova mlýna, který leží v údolí řeky Brziny. Také Brzina má problémy s vodou každý rok, ale většinou se nízké průtoky objevují až v záríi. Podobný transfer zvažovali ochránci prírody také na Jesenicku, kde bylo na potoce Krasovka jednou z alternativ záchrany raků z vysychajícího toku přemístit je do nižších vodnatějších částí toku. Tato varianta je $v$ prípadě záchranných transferů z důvodu sucha vždy preferovaným řešením - samožrejmě v prípadě, kdy se podmínky (rozuměj typ habitatu a kvalita vody) príliš neliší.

$K$ největšímu úhynu došlo na řece Třebovce v České Třebové. Efekt sucha zde byl umocněn př́valovým deštěm - prudký déšt se silně ohřál na rozpálené asfaltové ploše príléhající k toku a stekl přímo do řeky. Otázkou je, zda se do ohřáté vody nevyplavily toxické látky z místní komunikace. $V$ řece uhynulo asi 300 kg raků a ryb.

$\checkmark$ řadě prípadů byla mezi suchem a úhyny nalezena také jasná spojitost s již uvedeným nevhodným hospodařením na rybnících. Například na Svinařském potoce došlo v srpnu roku 2015 následkem zavření výpusti rybníka a nedodržení minimálního zůstatkového průtoku k úhynu ryb i raků. V toku se sympatricky vyskytuje rak říční a rak kamenáč. Př́padem se zabývala ČlŽP, ale potok byl již tak vyschlý, že i po zásahu ČıŽP, na jejíž podnět byl zvýšen průtok vody v potoce pod rybníkem, nedošlo ke zvýšení hladiny vody v místech s výskytem raků. Ačkoliv Svinařský potok je silně meliorován, v místech s výskytem raků je lemován smíšeným lesem, který rakưm poskytuje dostatek úkrytů v kořenech stromů zasahujících do toku a také stín, potřebný k prekonání kritického období. Oba druhy tak mohly přečkat nepríiznivé období v refugiích; definitivní záchranu pro oba druhy raků přinesla až změna počasí s dlouho očekávánými srážkami. Dalším místem sporu se stala říčka Desná u Litomyšle, kde podle tvrzení ochránců prírody ze záchranné stanice měly mít rybníky u Budislavi zavřené výpustě. Prípadem se zabýval odbor životního prostředí v Olomouci, tvrzení se ale nepotvrdilo. Následkem sucha na říčce uhynulo pět set raků, dalších asi tisíc raků se ochráncům povedlo zachránit. Ve spolupráci s hasiči byla zatopena tůn̆, kam se přeživší raci stáhli a ochránci je poté rozvezli do okolních lomů, kde by měli sucho prežít.

$\checkmark$ roce 2015 negativně ovlivnilo zhoršené podmínky na tocích i čerpání vody z toků. Na Trusovickém potoce došlo k téměř naprostému vyschnutí toku, nebot voda byla odčerpávána na zavlažování chataři, zahrádkáři a provozovateli sportovního hřiště. K velkému odběru vody dochází i proto, že obec využívá potok na obměnu vody v místním koupališti. Je zdokumentováno, že tento jev se zde opakuje každoročně. V extrémně teplých letních měsících došlo v letech 2012 a 2015 téměř k vyschnutí potoka a ryby bud' uhynuly, nebo byly přesunuty do jiných řek. V roce 2015 bylo magistrátem města Olomouc na popud MO ČRS Olomouc zakázáno jakékoli čerpání vody z potoka. A podobně jako v prípadě Janovského potoka, prestože jsou na tomto toku opakovaně problémy s množstvím vody a vysycháním, byli zde v roce 2007 vysazeni (v rozporu s legislativou) raci ríční.

Nejzávažnějším problémem sucha a s ním spojenými záchrannými transfery je ovšem prípadná spojitost s račím morem. Přestože symptomy provázející nákazu račím morem jsou charakteristické (raci jsou neklidní, opouští úkryty, hynou, zatímco ryby bez problémů přežívají), pro neodborníky mohou umírající raci nakažení račím morem vypadat velmi podobně jako raci umírající v důsledku nízké kvality vody nebo „sucha“. V roce 2015 došlo k úhynu na Kornatickém a Hádeckém potoce na jižním Plzeňsku. Tento úhyn byl bohužel způsoben račím morem. Byl řešen na úrovni státní správy (MŽP, KÚ Plzeňského kraje), rybářů (ZÚS ČRS) a také v médiích. V následujícím měsíci došlo ke zhoršení sucha v okolních tocích, na Chocenickém potoce a na Přešínském potoce. Zde došlo k př́kladnému řešení - rybářský hospodář oznámil celou situaci jednomu z autorů tohoto článku (P. Vlach) a následně byl proveden odborný transfer D. Fischerem. Úhyny, ohlášené na Chocenickém potoce OŽP MěÚ v Blovicích, byly konzultovány s P. Vlachem; v tomto prípadě se jednalo většinou o svlečky raků (viz dále). Pozitivní na celé věci byl fakt, že veřejnost informovaná o rizicích račího moru reagovala uváženě a správně.

$\checkmark$ roce 2014 byl na řece Vrchlici u Denemarkova mlýna zaznamenán hromadný úhyn raků. Byl vyloučen vliv havárie jakosti vody, zato po odborném vyšetření byl potvrzen račí mor. Populace raků nad přehradou u Chlístovic zůstala zachována - přehrada působila jako migrační bariéra a postup onemocnění tokem se zastavil. V červenci roku 2015 však byla Vrchlice nad přehradou v okolí obce Chlístovice téměř suchá; přestože neuplynul ani rok od nákazy račím morem a pravděpodobnost, že někteři nakažení jedinci nebo alespoň spory ještě mohly zůstat živé, byla velmi vysoká, místní obyvatelé přenesli živé raky do dolního toku - na místo infekce (ústní sdělení Ing. T. Just).

\section{ZÁVĚR ANEB CO NIKDY NEDĚLAT, A CO NAOPAK UDĚLAT}

Situace roku 2015 se může kdykoliv opakovat. Letošní zima nepřinesla dostatek sněhových srážek, což může vést k poklesu hladiny podzemních vod a společně s nedostatkem srážek v letním období budou uživatelé tlačeni k co největšímu zadržování vody v nádržích nebo na jezech.

\section{JAK SE TEDY ZACHOVAT, POKUD NALEZNEME VYSYCHAJÍCÍ TOK, VE KTERÉM HYNOU RACI}

V první řadě - pro laika je obtížné odlišit invazní severoamerické druhy raků od druhů původních. Jsou časté prípady, kdy laická veřejnost v dobré víre zachraňovala nepůvodní druhy raků, jako je rak pruhovaný nebo rak signální. Pokud jsou tito invazní raci přeneseni na lokality s výskytem raka rričního nebo raka kamenáče, hrozí velké nebezpečí, že celá populace našich původních raků vyhyne $v$ důsledku infikace račím morem, kterým mohou být přenesení raci s vysokou pravděpodobností nakaženi. Ale ani pokud raci nakaženi račím morem nejsou, nemají naši raci ještě vyhráno. Invazní raci jsou daleko agresivnější, častěji a dřive se rozmnožují a mají daleko více potomků [10]. Mnohdy je jen otázka času, za jak dlouho pưvodní raky, ale i další vodní živočichy z lokality vytlačí.

Lepší variantou je, pokud ochránci prírody zachraňují původní raky, ale i zde hrozí mnoho rizik např. v podobě přenosu různých nemocí na nové lokality, které opět mohou vyhubit původní populace raka říčního nebo kamenáče v jiném povodí. Na každé lokalitě je jen omezený počet úkrytů a pokud jsou raci preneseni na jiný potok nebo rybník, dojde ke konkurenčnímu boji o vhodné úkryty, o potravu atd. Slabší a menší raci v tomto prrípadě skončí jako potrava pro silnější jedince. Jedinou útěchou tak je, že raci nehynou přímo před očima ve vyschlém toku, ale podlehnou až v následném konkurenčním boji ukryti pod hladinou.

Ale i nalezené „mrtvolky rakư" mohou být pro laika zavádějící. Rak rychle roste, a proto se až několikrát ročně svléká a v toku po něm zůstane tzv. svlečka (exuvie), kterou laik rozezná od mrtvého raka jen stěží - vodítkem může být zápach, zatímco svlečka nezapáchá, zápach delší dobu mrtvého raka představuje velmi intenzivní zážitek. Konkrétně druhá polovina léta je obdobím, kdy dochází ke svlékání raků, takže při podrobném průzkumu lze snadno zjistit, že raci se uchýlili do vlhkých úkrytů, a ve vysychajícím potoce leží jen jejich odložené exuvie. 


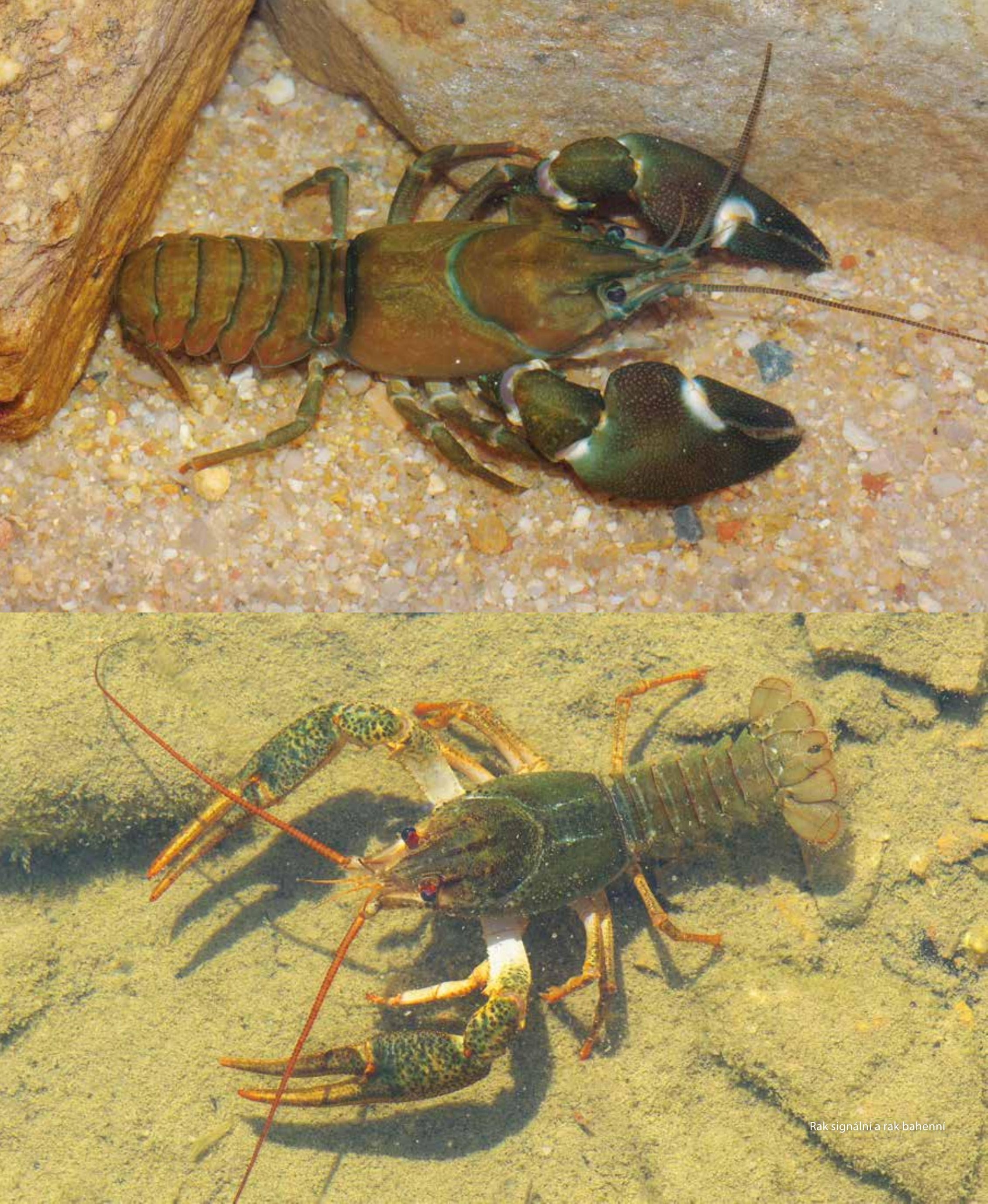


Záchranný transfer raků není záležitostí pro laika [11]. Pokud je jasné, že chceme přemístit původní druhy i přesto, že víme, že populace je zdravá, je tu další problém - a to najít vhodnou lokalitu, na kterou budou raci přemístěni. Pokud se podaří nalézt potok, kde zaručeně (ale to nelze nikdy stoprocentně zaručit) nejsou naši původní raci, má to vždy nějaký důvod - jakost vody v toku nevyhovuje nárokům raka řičního nebo kamenáče, na potoce dochází k haváriím jakosti vody, v potoce je málo úkrytů, není zastíněný nebo se někde v povodí nacházejí invazní raci.

Všechny výše vyjmenované důvody vedly k zavedení platné legislativy [3, 4], která raka říčního i raka kamenáče řadí mezi druhy kriticky ohrožené. Z těchto důvodů jsou manipulace s jedinci všech vývojových stadií, stejně jako škodlivé zásahy do jejich přirozeného vývoje i biotopu, zakázány. Je zakázáno raky chytat, rušit, přemístovat, držet, chovat v zajetí, dopravovat, prodávat, vyměňovat, nabízet za účelem prodeje nebo výměny, zraňovat, ničit, poškozovat či usmrcovat, a to ve všech jejich vývojových stádiích. Stejně jako zvláště chráněný živočich je chráněn i mrtvý jedinec tohoto druhu, jeho rozpoznatelná část nebo výrobek z něho. Chráněná jsou rovněž jimi uživaná přirozená i umělá sídla a jejich biotop

Proto s raky ve vysychajících tocích pokud možno nemanipulujte a informujte o situaci místně príslušný odbor životního prostředí obce $s$ rozšířenou působností nebo regionální pracoviště Agentury ochrany prírody a krajiny ČR. Ti zajistí odborné posouzení a identifikaci, o jaký druh raků se jedná, aby nedocházelo k neefektivní a především nežádoucí záchraně zavlečených druhů a přenosu račího moru, a prípadně navrhnou a zkoordinují další opatření.

\section{Poděkování}

Článek vznikl s podporou grantu EHP z Islandu, Lichtenštejnska a Norska Monitoring lokalit soustavy Natura 2000 jako nástroj pro efektivní management a ochranu autochtonnich populací rakü.

\section{Literatura}

[1] DAŇHELKA, J., BOHÁČ, M., CRHOVÁ, L., ČEKAL, R., ČERNÁ, L. aj. Vyhodnocení sucha na území České republiky v roce 2015. Předběžná zpráva, Český hydrometeorologický ústav, 2015, 73 s.

[2] ZAHRÁDKOVÁ, S., HÁJEK, O., TREML, P., PAŘIL, P., STRAKA, M., NĚMEJCOVÁ, D., POLÁŠEK, M. a ONDRÁČEK, P. Hodnocení rizika vysychání drobných vodních toků v České republice. VTEI, roč. 57, 2015 č. 6, s. 4-16

[3] Zákon č. 114/1992 Sb., o ochraně přírody a krajiny, ve znění pozdějších předpisů.

\section{[4] Vyhláška MŽP ČR č. 395 /1992 Sb.}

[5] VLACH, P., HULEC, L., and FISCHER, D. Recent distribution, population densities and ecological requirements of stone crayfish. Knowledge and Management of Aquatic Ecosystems, 13, 2009, p. 394-395. [6] FISCHER, D., PAVLUVČÍK, P., SEDLÁČEK, F., and ŠÁLEK, M. Predation of the alien American mink, Mustela vison on native crayfish in middle-sized streams in central and western Bohemia. Folia Zoologica, 58, 2009, p. 45-56.

[7] SVOBODOVÁ, J., DOUDA, K., FISCHER, D., LAPŠANSKÁ, N., and VLACH, P. Toxic and heavy metals as a cause of crayfish mass mortality from acidified headwater streams. Ecotoxicology, 2016, v recenzním řizení.

[8] VLACH, P., SVOBODOVÁ, J., and FISCHER, D. Stone crayfish in the Czech Republic: how does its population density depend on basic chemical and physical properties of water? Knowledge and Management of Aquatic Ecosystems, 2012, 407, 5

[9] ŠTAMBERGOVÁ, M., SVOBODOVÁ, J., and KOZUBíKOVÁ E. Raci v České republice. Praha: AOPK ČR, $2009,255 \mathrm{~s}$.

[10] VORBURGER, C. and RIBI, G. Aggression and competition for shelter between a native and an introduced crayfish in Europe. Freshw. Biol., 1999, 42, p. 111-119.

[11] KOZÁK, P., KOUBA, A., BUŘIČ, M., KUKLINA, I., FOŘT, M., VESELÝ, L. a POLICAR, T. Záchranné transfery rakư, Sborník abstraktů z XV. České rybářské a ichtyologické konference (RyblKon 2016), $73 \mathrm{~s}$.

\section{Autoři}

RNDr. Jitka Svobodová

凶jitka_svobodova@vuv.cz

Mgr. David Fischer ${ }^{2}$

凶david-fischer@centrum.cz

\section{Eva Svobodová1}

凶eva_svobodova@vuv.cz

RNDr. Pavel Vlach, Ph.D. ${ }^{3}$

凶vlach.pavel@mybox.cz

'Výzkumný ústav vodohospodářský T. G. Masaryka, v. v. i.

${ }^{2}$ Hornické muzeum Príbram

${ }^{3}$ Fakulta pedagogická, Západočeská univerzita v Plzni

Příspěvek prošel lektorským řízením.

\section{PERIODIC DROUGHTS IN STREAMS: THE NEXT NEGATIVE FACTOR INFLUENCING CRAYFISH POPULATIONS}

\section{SVOBODOVA, J.'; FISCHER, D. ${ }^{2}$; SVOBODOVA, E.'; VLACH, P. ${ }^{3}$}

${ }^{1}$ TGM Water Research Institute, p. r. i.

${ }^{2}$ Mining Museum Př́bram

${ }^{3}$ Center of Biology, Geosciences and Environmental Education, Faculty of Education, University of West Bohemia

Keywords: Austropotamobius torrentium - Astacus astacus drought - negative factor - invasive species - crayfish plague

Periodic droughts in small streams are caused by climate changes but also by the inappropriate management of precipitation and surface water. If these factors act simultaneously, water level rapidly declines even up to the complete drying up of long sections of the stream. Such changes are often fatal for aquatic fauna and particularly for protected crayfish species.

This contribution brings a couple of stories in 2015 connected with drought, crayfish and their rescue transfers. These rescue transfers were made incorrectly in many cases, without the appropriate permition and could hurt more than help. Therefore, this contribution also deals with legislative and technical aspects of such rescue transfers and also suggests how to properly proceed in these cases. 